\title{
DiSSEMINATION OF ENGINEERING EDUCATION AT SCHOOLS AND ITS ADJUSTMENT TO THE NEEDS OF ENTERPRISES
}

\author{
Eduard Shevtshenko, Tatyana Karaulova, Maris Igavens, Gunars Strods, \\ Ilona Tandzegolskiene, Vidmantas Tutlys, Tavahodi Seyed \& Vladimir Kuts
}
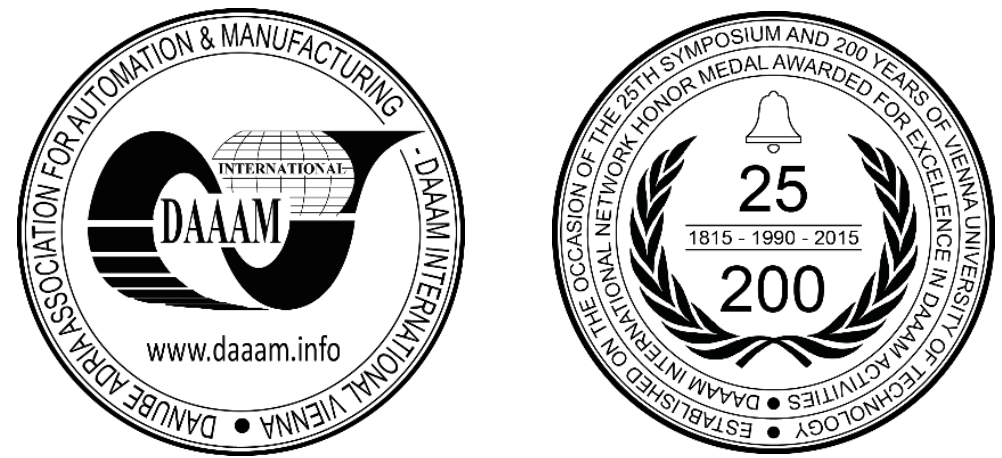

This Publication has to be referred as: Shevtshenko, E[duard]; Karaulova, T[atyana]; Igavens, M[aris]; Strods, G[unar]; Tandzegolskiene, I[lona], Tutlys V[idmantas], Tavahodi S[eyed] \& Kuts, V[ladimir] (2017). Dissemination of Engineering Education at Schools and its Adjustment to Needs of Enterprises, Proceedings of the 28th DAAAM International Symposium, pp.0044-0053, B. Katalinic (Ed.), Published by DAAAM International, ISBN 978-3-90273411-2, ISSN 1726-9679, Vienna, Austria

DOI: $10.2507 / 28$ th.daaam.proceedings.006

\begin{abstract}
In recent years, there has been a constant deficit of students in technical specialities in higher educational institutions. This problem is especially significant for industrial engineering area. To solve this issue, the authors initiated the joint project with participation of three universities in the Baltic region. This project aims to develop a new approach for preparing schoolchildren to choose the right profession through collective efforts of university, schools and enterprises. Authors address the critical issue in this paper, the gap between the needs of companies in the region and university education. Authors introduce this problem based on the questionnaire answers provided by the metal and machinery industries of the Baltic countries. Results of the current analysis may be useful to other nations and readers can apply them to other sectors.
\end{abstract}

Keywords: CDIO; IMATEII; teaching strategy; design, technologies and economics competencies; machinery industry; questionnaire

\section{Introduction}

In the new market relation, a central task for the schools is to provide children with a powerful platform of knowledge. This knowledge can help children to find worthy places in the society and grantee their successfulness in the future. There is evidence that teaching method plays a crucial role in developing children's interest toward the choosing of future profession. As a result, the elements of novelty in performing learning tasks are among the most critical factors for this development.

Recent developments in the higher education led to growing trend in youth's orientations, toward top statuses in the society. The presence of a diploma of higher education is one of the leading motives for admission to universities. Therefore, a significant proportion of young people tempts to select prestigious profession in their opinion in the future such as a programmer, a lawyer, financier, economist, and entrepreneur. However, labour market, in addition to these high statuses jobs, urgently requests for qualified engineers and technicians, and not always with higher education. As a 
result, often qualification of young specialists is inadequate to fulfil the real needs of the labour market. Investigations through manufacturing and industrial sectors have shown that engineers, technologists and other technical jobs are among the most popular professions [1].

Despite recent developments in higher education, the significant number of children still have problems with choosing their future career. In fact, their interest in professions is mainly unformed and blurred, and merely small parts of them think about future job and employment after graduation. The misconception about engineering profession has led to the lack of positive motivation toward these fields and their unpopularity between young people.

After Baltic countries have joined the EU, students can improve their professional level in other European countries. Often people leave their own country because they have not complete information about the opportunities to obtain the appropriate speciality in own country. Therefore, students usually break studies and leave their country seeking for the suitable position abroad, because they have no information about of all aspects selected profession. For schoolchildren to orient themselves in the professional sphere and realise themselves in the interests of the country, it is necessary to help them solve one of the most difficult and important questions, ,who I want to be?". The correct choice of high school students of their future profession will make the education process full and productive. A significant role in professional orientation belongs to higher education institutions.

In recent years there has been a constant shortage of students in higher education institutions for engineering specialities. For example, in Tallinn University of Technology (TUT) for several years the number of offered places in groups is higher than the number of students admitted (see Fig. 1). However, the number of student embraces the students from foreign country mostly Asian and African countries. This year TUT statistic shows the number of 53 for Industrial Engineering specialisation students, but only 11 of them were from Estonia. However, the role of demographic decline and openness of borders in the EU is undeniable, and this shortage emanates from low awareness of school children about the benefits of obtaining an education in own country.

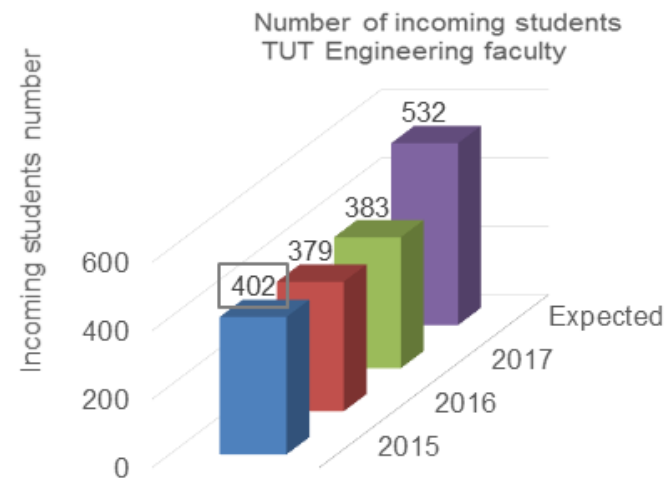

Fig. 1. Number of students coming to Engineering Faculty according to TUT statistic data

The other serious problem is the gap between the needs of the regions and education response in the area of the Career Guidance at secondary schools and introduction of youth with professions demanded in selected industries. Universities mostly focus on developing and assessing the knowledge competencies of future engineers, while employers needs skills that allow university graduates solving actual engineering problems immediately upon graduation.

For solving these problems the universities of the Baltic region: Rezekne Academy of Technologies, Vitautas Magnus University and Tallinn University of Technology starts the project "Innovative methods and technologies of education for implementing interdisciplinary (IMATEII) in career guidance. The purpose of this investigation is optimisation of opportunities in labour market by increasing the number of professionals in the strategic business of Baltic Sea countries.

The researchers set out the following objectives for the current project:

- develop and implement innovative practices in career education at secondary school,

- promote secondary school teachers the career guidance competence based on interdisciplinary among design, technology and economics,

- facilitate motivated and targeted career choice of learners in selected fields of industries.

\section{CDIO modern approach to engineering education}

The CDIO (Conceive - Design - Implement - Operate) initiative is an international collaboration between engineering schools for engineering education reconstruction to fulfil the industry requirements. Massachusetts Institute of Technology (MIT) has founded the basis of CDIO at in the late 1990s, since then, it was significantly enlarged and include many schools across North America, Europe, Asia, Africa and Australia and Russia. The Department of Mechanical and Materials Engineering (MME) is an official collaborator of the CDIO Initiative since 2003 [2]. CDIO initiative became the most exhaustive and holistic system of standards among others. Many universities have become the participants of CDIO world initiative applying and implementing similar approaches. In addition, many universities have disseminated 
these methods in schools and students now are involved in scientific and project activities under the supervision of both university and school teachers [3]. CDIO initiative sheds new light on "how universities can continually provide highquality education in technical fields, while simultaneously imparting a sense of engineering professions in students." Primary concern of CDIO is narrowing the existing gap between engineering education and practice [4], [5].

The CDIO process includes [6], [7]:

"Conceive" stage is a creative process of conceiving new structures for technical devises and systems. At this stage should be considered: customer needs, technology, enterprise strategy, regulations, and conceptual, professional and business plans. Many universities using TRIZ in their educational practice for the rising of students' ability to generate ideas, which helps to find an exciting solution, create new product or system [8], [9], [10]. In addition, TRIZ is widely used by many leading transnational corporations for inventive solutions development.

At „Design" stage, teachers should consider plans, drawings, and algorithms that identify the necessary items of this process. Usually, teachers employ CAD, CAM, and CAE programs at this stage. In addition to calculations, "Design" stage can also include the experimental part supported by the systems of multidimensional simulation [11]. To simplify the understanding of Design stage for particular domain it is also possible to create the virtual 3D rooms for professional activities [12].

"Implement" stage is an applying the design in product, process, or system which embraces manufacturing, coding, testing and validation. "Operate" stage is an applying the design in product, process, or system which embraces manufacturing, coding, testing and validation. "Operate" stage includes the implementation of product or process that presenting the intended value. This phase consists of the maintaining, evolving and retiring the system. The university can successfully implement the last two stages in industrial premises in collaboration with partner enterprises.

Applying CDIO principles in engineering education significantly change the conventional approach to educational programs development and implementation and, as a result, enhance the competence of the graduates and increase their competitiveness in the international engineering labour market.

Selected authors have introduced ideas and approaches on emerging skills development [13]. Taajamaa et al. [14] have suggested adding "design thinking" methods [15] to the front and end of CDIO process, thereby exposing and providing students with the tools for dealing with complex, multidisciplinary problems. This method is significantly helpful when problem identification itself is quite challenging. Campbell and Beck [16] proposed a CDIO standard for internationalisation and mobility. Enelund et al. [17] suggested a concept for a computational mathematics curriculum, for engineering students.

Teachers have conducted two first projects in Scandinavia and the Baltic Sea region (Turku University of Applied Sciences and Helsinki Metropolia University of Applied Sciences from Finland, Royal Institute of Technology from Sweden and Technical University of Denmark, the Tartu University from Estonia and Vilnius University of Applied Sciences from Lithuania). By offering new innovative models and tools, these projects promote "the quality assurance work and continuous curriculum development in the field of engineering science in Baltic partner universities" [18].

The authors of the current project with participants from three Baltic state countries: Latvia, Lithuania and Estonia are also using CDIO principles with some particular differences. In addition to CDIO guidelines, it also includes economic aspect. Most exciting part is the assessment of such factors as external senses and working conditions during the enterprise visits (visual impression, noise, smell, staffs' attitude etc.), what gives the full expression ("colour") about the selected profession.

\section{Project implementation}

Adequate training of qualified specialists for the metal and machinery industry is possible only in close cooperation between the schools, universities and enterprises. University educational programs should correspond to the needs of the industrial companies developed in particular region. Therefore, there is the need for the constant monitoring of the competencies of the participants in the educational and the production systems.

The task for project first activity was to collect information on employers needs corresponding to their staff competencies in design, technology and economics areas and elaborating recommendations for career counsellor inservice training program development. The project team have used the questionnaire for data collection.

Researchers have divided the analysis tasks between universities by several industrial domains: forestry and wood, metal and machinery, agriculture and food sectors of industry. The project work was carried out in all areas according to the general scheme presented in Fig. 2. The current paper introduces the domain of metal and machinery industry, which is one of the most important growth areas in Estonia. There are more than 2000 metalworking and machine building companies, employing more than 35000 employees, but the average percentage of dropouts in Estonian higher schools was $20 \%$ during the last three years. The sector needs more engineers whose skills and knowledge are suitable for starting work after graduating, for developing the business that creates bigger added value [19].

\subsection{Dissemination of the engineering education in schools}

The primary objective of this project is to attract and train students in schools for admission to the Higher Educational Institutions with technical specialisation. Within the framework of this project, the main emphasis is on familiarizing the students with the realities of the chosen profession through visits to enterprises and master classes in school and university laboratories. It is essential to show the students how companies make the selected product. Fig. 3 shows the primary collaboration function between the project group members from university and schools. 


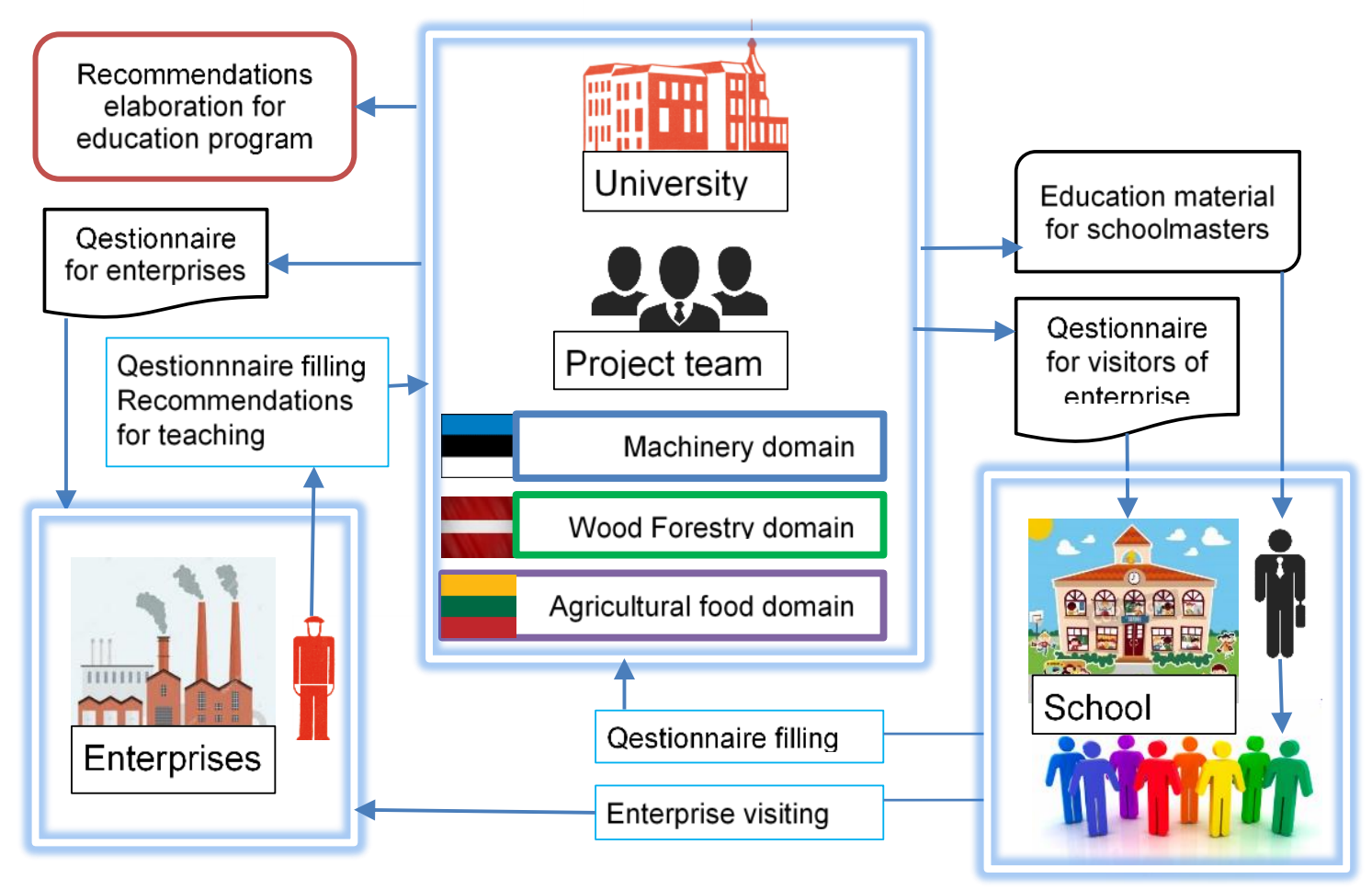

Fig. 2. General scheme of project implementation

The first step is to establish the contacts with schools and enterprises of a particular area. Project leaders must consider a possible list of products to show lifecycle from design to end-product may (products library) to schoolchildren (products library). The students select the most exciting product for studying by themselves. The project team can choose different company products to show, but highlight those products, which production process teachers will show youngsters while visiting university partners companies.

Each product from „Product library" must have the description of it technological process (Technologies library). It must be done on the reasonable level for schoolchildren, as short description, film, illustration. University lecturers and researchers prepare slides and training materials to give over to schoolteachers the technological knowledge and skills. Schoolmaster explain to the students based on practical lessons how to design and manufacture the selected product, supported by the university lecturers.

In addition, project leaders must organise visits to the companies, which produce the previously studied products, so that the pupils have a complete view of a real manufacturing process and production environment. It is essential because often working conditions and sensorial feelings are playing the critical role in choosing a future profession. Our project team elaborated the questionnaire for self-checking of the sensual impressions for company visitors.

\begin{tabular}{|c|c|c|c|c|c|}
\hline \multirow[t]{2}{*}{ Sense } & \multicolumn{4}{|c|}{ Attitude } & \multirow[t]{2}{*}{ Comments } \\
\hline & Like & Mostly like & Mostly don't like & Don't like & \\
\hline Smell & & & & & \\
\hline Touch & & & & & \\
\hline Visual & & & & & \\
\hline Temperature & & & & & \\
\hline Wet & & & & & \\
\hline Dust & & & & & \\
\hline Safety & & & & & \\
\hline Staff attitude & & & & & \\
\hline
\end{tabular}

Table 1. Questionnaire for enterprise visitors

Work in classroom with schoolchildren must base on teaching and learning strategies [20]. In these recommendations given samples how to implement critical thinking teaching and learning strategies in career guidance and to allow students from secondary school to introduce with local industries through Design, Technologies and Economics competencies development. 


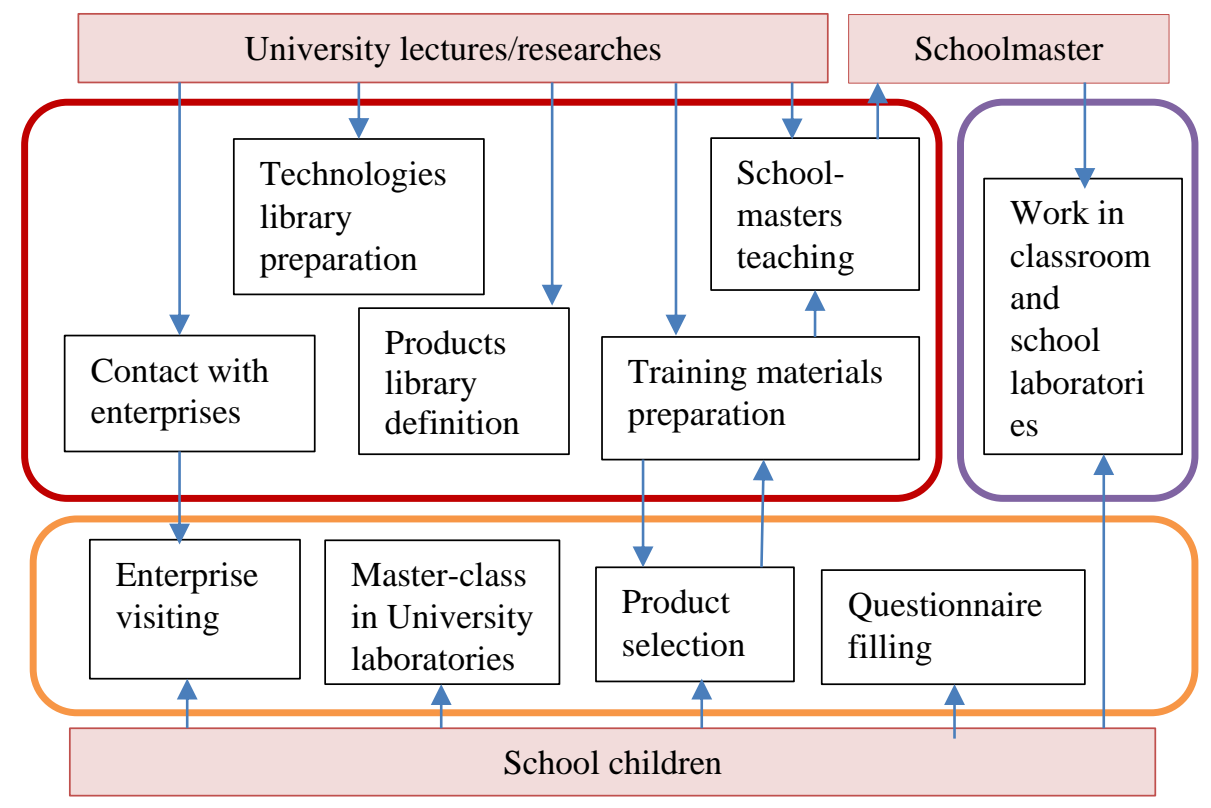

Fig. 3. The primary functions of university and school in frame of current project

\subsection{Analysis of Enterprises needs for machinery industry in the Baltic region.}

The target of the project is to synchronise the needs of engineering enterprises with the curricula of universities in the Baltic Sea area. For this purpose, authors have surveyed firms from three Baltic state countries on three core competencies identified by the teaching and learning strategies. The researchers have prepared the questionnaire for enterprises skills in design, technology and economics based on Latvian professional standard [21]. In this project, each country has selected the area of primary competence, Estonian researchers have selected the machinery domain; Latvian project team have chosen the wood industry, and Lithuania have the most significant experience in the food industry. In this article, authors are focusing only on machinery domain. The questionnaire is universal, and readers can apply it to other sectors.

\begin{tabular}{|l|l|}
\hline $\mathbf{N r}$ & Competences related to DESIGN \\
\hline $\mathbf{1}$ & Creative and independent development of existing and new products \\
\hline $\mathbf{2}$ & $\begin{array}{l}\text { Exploring the needs of the ultimate users and forecasting all the experience-based design aspects, technology, } \\
\text { material and fashion trends. }\end{array}$ \\
\hline $\mathbf{3}$ & $\begin{array}{l}\text { Creating long-term product: innovative, functional, produce in a rational and cheaper way, convenient and } \\
\text { easy to use, with aesthetically high-quality forms. }\end{array}$ \\
\hline $\mathbf{4}$ & Formulating basic design tasks and to planning artistic design and construction works. \\
\hline $\mathbf{5}$ & Analysis and definition of logistical, functional, aesthetical, and ergonomic set of qualities. \\
\hline $\mathbf{6}$ & $\begin{array}{l}\text { Navigating and managing used materials, to analyse their improvement and development trends, and to be } \\
\text { able to use them at work. }\end{array}$ \\
\hline $\mathbf{7}$ & Setting products' manufacturing restrictions and choosing a set of possible solutions \\
\hline $\mathbf{8}$ & $\begin{array}{l}\text { Developing products, including sketches of collection or series conceptual solution, maps and digital three- } \\
\text { dimensional visualisations and organisation and carrying out model }\end{array}$ \\
\hline $\mathbf{9}$ & Developing of projects by using CAD and CAM technologies. \\
\hline $\mathbf{1 0}$ & Preparation of project materials for presentation \\
\hline $\mathbf{1 1}$ & Developing equipment monitoring and visualization schemes. \\
\hline $\mathbf{1 2}$ & $\begin{array}{l}\text { Designing in compliance with the universal design principles, applying innovative approaches and } \\
\text { technological developments. }\end{array}$ \\
\hline $\mathbf{1 3}$ & $\begin{array}{l}\text { Carrying out project presentation and coordination with the contractor and responsible departments in } \\
\text { various product development stages. }\end{array}$ \\
\hline $\mathbf{1 4}$ & Preparing and conducting presentations, managing shows and exhibitions \\
\hline
\end{tabular}

Table 2. Competencies related to design

The purpose of the questionnaire is to identify the most significant aspects of preparing the specialists for machinery industry. To collect information on requirements that employers request to their staff in design, technology and economics and elaborate the recommendations for career counsellor in-service training program development. 
The authors have collected the 30 answers from machinery domain companies of three countries: 11 respondents from 8 enterprises in Latvia; 4 respondents from 2 firms in Lithuania; 15 respondents from 7 businesses in Estonia. Each respondent was asked to assess the relevance of various work processes related to the company's activities and their future development. The questionnaire includes 66 items: 14 questions related to design (see Table 2), 30 related to technology (see Table 3) and 22 connected to the economy (see Table 4). Authors have asked to assess each skill described in the questionnaire on a 10-point scale, where 10 "very, very necessary" and 0 "not necessary". Respondents have provided information on their company name, position, age and level of education. The authors are introducing the results of the questionnaire in tables (Table 2, Table 3 Table 4, Table 5, Table 6) and related diagrams (Fig. 4, Fig. 5, Fig. 6).

\begin{tabular}{|c|c|c|c|c|c|c|c|c|c|c|c|c|c|c|c|c|}
\hline & \multirow[b]{2}{*}{ Enterprise } & \multirow[b]{2}{*}{ Position } & \multicolumn{14}{|c|}{ Number of activity for DESIGN competence } \\
\hline & & & 1 & 2 & 3 & 4 & 5 & 6 & 7 & 8 & 9 & 10 & 11 & 12 & 13 & 14 \\
\hline $\mathrm{EE}$ & Enterprise 1 & Top manager & 7 & 5 & 7 & 7 & 10 & 7 & 7 & 7 & 8 & 7 & 9 & 7 & 8 & 7 \\
\hline $\mathrm{EE}$ & nterprise 2 & Head of dep. & 10 & 10 & 10 & 10 & 8 & 10 & 8 & 8 & 10 & 7 & 7 & 7 & 8 & 7 \\
\hline $\mathrm{EE}$ & nterprise 2 & Specialist & 8 & 8 & 8 & 8 & 7 & 10 & 10 & 10 & 9 & 7 & 0 & 9 & 8 & 7 \\
\hline $\mathrm{EE}$ & nterprise 3 & of dep. & 8 & 8 & 10 & 10 & 7 & 10 & 7 & 7 & 8 & 6 & 0 & 8 & 8 & 5 \\
\hline $\mathrm{EE}$ & aterprise 3 & Top manager & 10 & 6 & 10 & 10 & 10 & 10 & 10 & 10 & 6 & 6 & 6 & 10 & 10 & 8 \\
\hline $\mathrm{EE}$ & aterprise 3 & Specialist & 9 & 10 & 8 & 6 & 5 & 8 & 3 & 9 & 10 & 9 & 9 & 10 & 8 & 8 \\
\hline $\mathrm{EE}$ & aterprise 4 & Spe & 8 & 9 & 10 & 10 & 9 & 8 & 9 & 8 & 8 & 8 & 9 & 10 & 9 & 8 \\
\hline $\mathrm{EE}$ & terprise 5 & f dep. & 8 & 10 & 8 & 5 & 5 & 8 & 7 & 7 & 8 & 8 & 8 & 6 & 9 & 7 \\
\hline $\mathrm{EE}$ & aterprise 5 & ialist & 10 & 5 & 10 & 10 & 6 & 10 & 10 & 6 & 10 & 10 & 6 & 10 & 6 & 6 \\
\hline $\mathrm{EE}$ & rise 5 & ager & 4 & 5 & 6 & 0 & 3 & 6 & 5 & 5 & 5 & 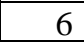 & 0 & 6 & 6 & 6 \\
\hline $\mathrm{EE}$ & rise 6 & Dep. & 4 & 6 & 3 & 3 & 2 & 5 & 3 & 3 & 8 & 0 & 0 & 5 & 4 & 4 \\
\hline $\mathrm{EE}$ & se 6 & & 8 & 7 & 9 & 6 & 10 & 5 & 5 & 10 & 8 & 4 & 6 & 9 & 10 & 10 \\
\hline $\mathrm{EE}$ & se 7 & ager & 6 & 7 & 7 & 7 & 6 & 7 & 8 & 7 & 10 & 8 & & 8 & 8 & 8 \\
\hline $\mathrm{EE}$ & se 7 & Dep. & 6 & 8 & 8 & 6 & 8 & 10 & 9 & 6 & 8 & 6 & 0 & 7 & 6 & 5 \\
\hline $\mathrm{EE}$ & Enterprise 7 & & 10 & 4 & 3 & 6 & 6 & 10 & 10 & 10 & 10 & 7 & 8 & 10 & 8 & 5 \\
\hline \multicolumn{3}{|c|}{ Average in Estonia } & 7,73 & 7,2 & 7,8 & 7,07 & 6,8 & 8,27 & 7,4 & 7,53 & 8,4 & 7,13 & 7,87 & 8,13 & 7,73 & 6,73 \\
\hline ET & Enterprise 8 & list & 9 & 10 & 8 & 6 & 5 & 8 & 3 & 9 & 10 & 9 & 9 & 10 & 8 & 8 \\
\hline E1 & ise 8 & dep. & 10 & 10 & 10 & 10 & 8 & 10 & 8 & 8 & 10 & 7 & 7 & 7 & 8 & 7 \\
\hline $\mathrm{E}^{\prime}$ & se 9 & ager & 7 & 5 & 7 & 7 & 10 & 7 & 7 & 7 & 8 & 1 & 34 & 7 & 8 & 7 \\
\hline ET & Enterprise 9 & $\mathrm{~S}$ & 8 & 8 & 8 & 8 & 7 & 10 & 10 & 10 & 9 & 7 & 8 & 9 & 8 & 7 \\
\hline \multicolumn{3}{|c|}{ Average in Lithuania } & 8,75 & 8,25 & 7,8 & 8,3 & 8,8 & 8 & 7,8 & 8,3 & 8,3 & 7,5 & 8,3 & 8,8 & 8,5 & 7,8 \\
\hline $\mathrm{LV}$ & Enterprise 10 & & 8 & 7 & 6 & 3 & 5 & 8 & 5 & 9 & 10 & 8 & 7 & 7 & 7 & 5 \\
\hline $\mathrm{LV}$ & se 10 & nager & 1 & 1 & 1 & 1 & 1 & 1 & 1 & 1 & 5 & 1 & 7 & 1 & 1 & 1 \\
\hline $\mathrm{LV}$ & ise 11 & ager & 4 & 3 & 5 & & 4 & 6 & 6 & 4 & 3 & 3 & $J_{1}$ & 2 & 4 & 4 \\
\hline $\mathrm{LV}$ & se 12 & & 7 & 7 & 7 & 7 & 7 & 8 & 8 & 8 & 8 & 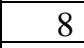 & 4 & 8 & 8 & 8 \\
\hline $\mathrm{LV}$ & ise 12 & ager & 7 & 7 & 7 & 7 & 7 & 7 & 8 & 8 & 8 & 8 & 7 & 8 & 8 & 8 \\
\hline $\mathrm{LV}$ & ise 12 & dep & 7 & 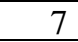 & 8 & 8 & 9 & 8 & 9 & 9 & 9 & 9 & 9 & 8 & 8 & $\overline{0}$ \\
\hline $\mathrm{LV}$ & se 13 & lep & 10 & 10 & 7 & 8 & 10 & 10 & 10 & 7 & 10 & 0 & 8 & 7 & 9 & 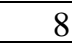 \\
\hline $\mathrm{LV}$ & rise 13 & ager & 10 & 8 & 7 & 7 & 8 & 9 & 7 & 8 & 9 & 8 & 7 & 9 & 8 & 9 \\
\hline $\mathrm{LV}$ & se 13 & & 8 & 9 & 9 & 3 & 9 & 9 & 7 & 3 & 3 & 3 & 1 & 1 & 1 & 1 \\
\hline $\mathrm{LV}$ & rise 14 & Top & 10 & 8 & 7 & 5 & 5 & 9 & 8 & 5 & 10 & 3 & 3 & 3 & 5 & 5 \\
\hline $\mathrm{LV}$ & Enterprise 14 & Spe & 9 & 9 & 9 & 3 & 9 & 9 & 7 & 3 & 3 & 3 & 1 & 1 & 1 & 1 \\
\hline \multicolumn{3}{|c|}{ Average in Latvia } & 7 & 6,7 & 6,4 & 5,44 & 6,5 & 7,5 & 6,9 & 6,2 & 7,5 & 5,9 & 5,6 & 5,4 & 5,9 & 5,8 \\
\hline
\end{tabular}

Table 3. Questionnaire results in competence related to design

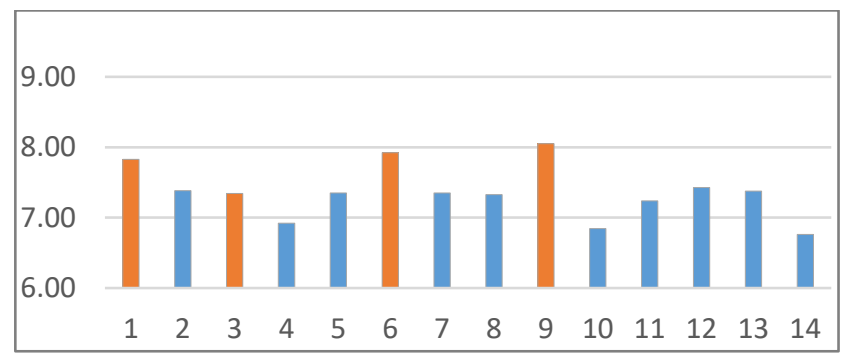

Fig. 4. Results of design activities estimation (by red are marked activities with more high grade)

Recommendations for design competence:

- Navigating and managing used materials, to analyse their improvement and development trends.

- Developing of projects by using computer-assisted design and computer-aided manufacturing technologies.

- Creative and independent development of existing and new products. 
- Creating long-term product: innovative, functional, produce in a rational and cheaper way.

- Setting products' manufacturing restrictions and choosing a set of possible solutions (possible material usage and compatibility as wells as possible constructive solution options).

- Analysis and definition of logistical, functional, aesthetical, and ergonomic set of qualities.

The authors have not included into the questioner the following design skills, which companies have marked as important: custom-made products design, standardisation, design for manufacturing and Assembly (DFMA), knowhow of reliability tools (DFEA, FMEA), quality management.

\begin{tabular}{|c|c|}
\hline Nr. & Competencies related to TECHNOLOGY \\
\hline 15 & $\begin{array}{l}\text { Developing a map of detail inspection, choosing the necessary instruments and calculating their amount, } \\
\text { aligning their conditions of use and storage to ensure the necessary quality. }\end{array}$ \\
\hline 16 & Diagnosing the service and repairs of assisting devices and ensuring their production, mechanisms, and tools. \\
\hline 17 & $\begin{array}{l}\text { Managing electrical and system production and installation; determining control samples and technological } \\
\text { processes to ensure the safety and efficiency of operation of electrical systems, engines and equipment. }\end{array}$ \\
\hline 18 & Developing technological planning of production \\
\hline 19 & Evaluating the level of production automation \\
\hline 20 & Performing linking of automated electrical equipment to technologies. \\
\hline 21 & $\begin{array}{l}\text { Managing the essential requirements for equipment (mechanical strength and stability (resilience), } \\
\text { environmental friendliness, safety of usage, application compliance, access to structures, rational use of } \\
\text { natural resources). }\end{array}$ \\
\hline 22 & Managing the production technology of Products and Service \\
\hline 23 & Contributing to introduction of new technologies \\
\hline 24 & $\begin{array}{l}\text { Developing, optimisation, and improvement of current product technologies and systems for generation, } \\
\text { distribution, transportation, utilization, and disposal. }\end{array}$ \\
\hline 25 & Conducting calculations and drawings independently by using necessary software. \\
\hline 26 & Conducting scientifically valuable research and implementing it into work. \\
\hline 27 & Planning, organization and control of work methods and technologies. \\
\hline 28 & Choosing most rational technique and technology. \\
\hline 29 & Managing technological processes \\
\hline 30 & Developing proposals which are directed to more efficient and useful recourse utilization \\
\hline 31 & Determining technological installations necessary for work implementation and planning their placement. \\
\hline 32 & Using latest information technologies \\
\hline 33 & Collecting and summarising necessary professional information and following topicalities of the field \\
\hline 34 & Conducting a professional work assignment analysis, \\
\hline 35 & Applying the principles of environmental friendly production \\
\hline 36 & Making strategic and operative decisions by summarizing and analysing production information. \\
\hline 37 & $\begin{array}{l}\text { Adjustment of production regimes by applying knowledge of production process. Organising technological } \\
\text { processes in complying with environmental laws and regulations. }\end{array}$ \\
\hline 38 & Organising technological processes in complying with environmental laws and regulations. \\
\hline 39 & Forming a safe workplace in complying with fire safety regulations in the production facility. \\
\hline 40 & Using rationally and recycling of sub-products acquired in the process. \\
\hline 41 & $\begin{array}{l}\text { Elaborating normative documents (technological instructions, quality manuals, technical regulations, etc.) } \\
\text { according to company specifics. }\end{array}$ \\
\hline 42 & Development of hygiene requirements for the production process. \\
\hline 43 & Using product labelling (by applying knowledge of the EAN). \\
\hline 44 & ng causes of the production incompatibility and taking preventive actions to address them. \\
\hline
\end{tabular}

Table 4. Competencies related to technology

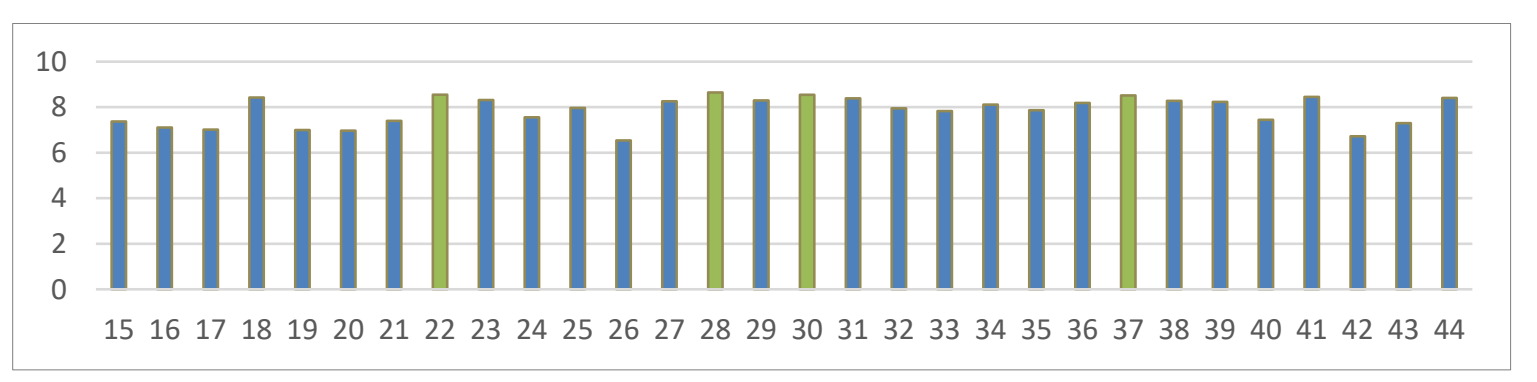

Fig. 5. Results of technology activities estimation (by green are marked activities with more high grade) 
Recommendations for technology competence:

- Choosing the most rational technique and technology.

- Contributing to the introduction of new technologies.

- Developing the technological planning of production

- Managing the production technology of Products and Services

- Forming a safe workplace, which meets the fire safety regulations in the production facility.

- Adjustment of the production regimes by applying knowledge of production process.

The authors have not included into the questionnaire the following technical competencies, which companies have marked as important: ability to perform the overview of scientific research and implement it in today's business; PokaYoke and 8D improvements; ability to learn from mistakes, analysis of the dimensional system.

\begin{tabular}{|l|l|}
\hline Nr. & Competencies related to ECONOMY \\
\hline $\mathbf{4 5}$ & $\begin{array}{l}\text { Evaluating the calculations of the cost of services to be performed, the necessary investments and workforce } \\
\text { consumption. }\end{array}$ \\
\hline $\mathbf{4 6}$ & Applying different management models. \\
\hline $\mathbf{4 7}$ & Navigating the European Union sector-specific policies and its implementation methods \\
\hline $\mathbf{4 8}$ & $\begin{array}{l}\text { Preparation of costs for designing or manufacturing equipment and determining the time of expenditure } \\
\text { reimbursement. }\end{array}$ \\
\hline $\mathbf{4 9}$ & Development of the most cost-effective technical solutions. \\
\hline $\mathbf{5 0}$ & Choosing and aligning materials with a client and planning economic material consumption \\
\hline $\mathbf{5 1}$ & Defining of strategic objectives. \\
\hline $\mathbf{5 2}$ & Running and planning operating strategy sector. \\
\hline $\mathbf{5 3}$ & Planning and organisation of complex resource use. \\
\hline $\mathbf{5 4}$ & Dealing with sector market \\
\hline $\mathbf{5 5}$ & Drawing up a business plan and estimates \\
\hline $\mathbf{5 6}$ & Handling problem situations adequately and timely adopting necessary decisions \\
\hline $\mathbf{5 7}$ & Defining tasks in achieving set targets in order to produce products with high added value \\
\hline $\mathbf{5 8}$ & $\begin{array}{l}\text { Using the necessary technical and normative documentation for the work, carrying out applied and } \\
\text { professional documents. }\end{array}$ \\
\hline $\mathbf{5 9}$ & Analysing sector benefits and assessing the competitiveness of the holding \\
\hline $\mathbf{6 0}$ & Calculation and evaluation of economic performance of the holding \\
\hline $\mathbf{6 1}$ & Assessment of risk factors of the particular holding and assessment of the measures to reduce the risk \\
\hline $\mathbf{6 2}$ & Navigating and using management accounting capabilities \\
\hline $\mathbf{6 3}$ & Development and management of projects \\
\hline $\mathbf{6 4}$ & Organising and controlling economic activities of the enterprise. \\
\hline $\mathbf{6 5}$ & Developing and implementing quality management and self-checking system \\
\hline $\mathbf{6 6}$ & Controlling the material and financial cash flow of the enterprise. \\
\hline
\end{tabular}

Table 5. Competencies related to economy

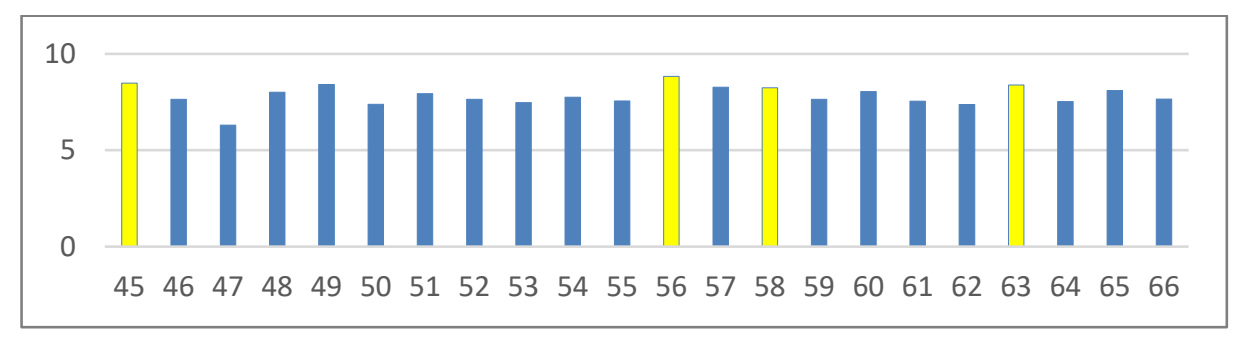

Fig. 6. Results of economy activities estimation (by yellow are marked activities with more high grade)

Recommendations for economy competence:

- Handling problem situations adequately and timely adopting necessary decisions.

- Evaluating the calculations of the cost of services to be performed, the necessary investments and workforce consumption.

- Development and management of projects.

- Using the necessary technical and normative documentation for the work, carrying out applied and professional documents

- Defining of strategic objectives.

- Development of the most cost-effective technology solutions. 
The economy competencies that are important, but authors have not included in the questionnaire are: defining of most cost-effective solutions; analyse the production processes by cost-intensive processes; understand the connections between different functions and departments; ability to see the whole Value Chain from Sales till Support operations; risk analysis; control plans and perform the process mapping.

Authors have introduced other critical skills in machinery sector in Table 6. From the overall results given in Table 6, it can be seen that enterprises are mostly consistent with suggested results.

\begin{tabular}{|c|c|c|c|c|}
\hline & & Avg & $\mathrm{Nr}$ & Competencies \\
\hline \multirow{4}{*}{ 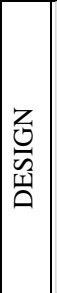 } & \multirow{4}{*}{ 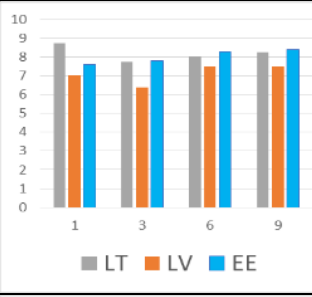 } & 8,03 & 6 & $\begin{array}{l}\text { Navigating and managing used materials, to analyse their improvement } \\
\text { and development trends, and to be able to use them at work. }\end{array}$ \\
\hline & & 8,03 & 1 & Creative and independent development of existing and new products. \\
\hline & & 7,6 & 3 & $\begin{array}{l}\text { Creating long-term product: innovative, functional, produce in a rational } \\
\text { and cheaper way, convenient and easy to use, with aesthetically high- } \\
\text { quality forms. }\end{array}$ \\
\hline & & 7,57 & 9 & Developing of projects by using CAD and CAM technologies \\
\hline \multirow{4}{*}{ 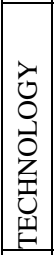 } & \multirow{4}{*}{$\begin{array}{c}9,5 \\
9 \\
8,5 \\
8 \\
7,5 \\
7 \\
\end{array}$} & 8,64 & 28 & Choosing most rational technique and technology \\
\hline & & 8,54 & 30 & $\begin{array}{l}\text { Developing proposals which are directed to more efficient and useful } \\
\text { recourse utilization }\end{array}$ \\
\hline & & 8,54 & 22 & Managing the production technology of Products and Services. \\
\hline & & 8,50 & 37 & $\begin{array}{l}\text { Adjustment of production regimes by applying knowledge of production } \\
\text { process }\end{array}$ \\
\hline \multirow{4}{*}{ 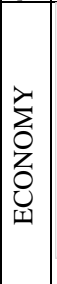 } & \multirow{4}{*}{$\left.$\begin{tabular}{l|l|l|}
8 \\
6 \\
4 \\
2 \\
0
\end{tabular}\right|$_{45}$} & 8,80 & 56 & $\begin{array}{l}\text { Handling problem situations adequately and timely adopting necessary } \\
\text { decisions }\end{array}$ \\
\hline & & 8,48 & 45 & $\begin{array}{l}\text { Evaluating the calculations of the cost of services to be performed, the } \\
\text { necessary investments and workforce consumption }\end{array}$ \\
\hline & & 8,38 & 63 & Development and management of projects \\
\hline & & 8,20 & 58 & $\begin{array}{l}\text { Using the necessary technical and normative documentation for the work, } \\
\text { carrying out applied and professional documents }\end{array}$ \\
\hline
\end{tabular}

Table 6. Four high ranked competencies in design, technology and economics in machinery sector

\section{Conclusions}

Since this project is not yet finished and the work in schools is still conducted by the project participants, authors are not ready to present the final results. The authors will receive the result by analysing the enrolment statistics of schools graduates into engineering faculty of Tallinn Technical University during the two year period. At the current stage of the project, authors see that the project will create the new and upgrade the existing technical knowledge and educational materials for qualified professional training teachers from schools and universities. The possibility to communicate with the enterprises will give a realistic impression of a selected profession to schoolchildren.

The analysis of the enterprise's needs revealed the most important aspects in the companies for studying, and it is essential to prepare the qualified specialists to solve them. The universities can use the analysis of project results during the development of educational programs.

The results of the project will be:

- Particularization of the gap situation between the needs of the regions and education response in the area of the Career Guidance at secondary schools and introduce youth with professions which are demanded in selected industries;

- The Career Counsellors and secondary school teacher in-service training course "Innovative methods and technologies of education for implementing interdisciplinary in career guidance (IMATEII)";

- $\quad$ Results of IMATEII piloting in secondary school;

- The delivery of new and upgraded knowledge together with interdisciplinary methods in secondary school classes;

- Promoted career counsellors and class teachers competencies in career education and guidance at secondary schools;

- The results of the implementation of new interdisciplinary methods disseminated;

- $\quad$ Best practice samples offered for career education and guidance practitioners.

\section{Acknowledgments}

This research supported by Erasmus + project VERT17065 - Innovative methods for implementing interdisciplinary in career counselling (IMATEII) and F15027 - Smart manufacturing and materials technologies competence centre. 


\section{References}

[1] Gorina E. \& Shikina Е. (2013) Features of the occupational choice: results of the trend research, УДК 316.334.2+331.5, Available from https://cyberleninka.ru/article/n/osobennosti-vybora-buduschey-professiirezultaty-trendovogo-issledovaniya Accessed: 2017-10-01

[2] Berggren, K.; Brodeur, D.; Crawley, E.; Ingemarsson, I.; Litant, W.; Malmqvist, J. \& Östlund, S. (2003) CDIO: An international initiative for reforming engineering education, World Transactions on Engineering and Technology Education Vol.2, No.1, 2003, pp 49 - 52.

[3] Sidorkina, O. \& Pogrebnaya, T. (2014) CDIO within the system of continuous education "From school to Higher Education Institution (HEI)": Stage "Conceive" at school. Journal of the Association for Engineering Education of Russia. Vol 16, 2014, pp.42-47.

[4] Woollacott, L. (2007) The goals of engineering education: a rationale for a universal document based on the CDIO syllabus and the taxonomy of engineering competencies, Proceedings of the 3rd International CDIO Conference, MIT, Cambridge, Massachusetts, June 11-14, 2007. Available from http://rocketship.cdio.org/files/document/file/T2A2Woollacott.pdf, Accessed: 2017-10-01.

[5] Crawley E. (2002)Creating the CDIO syllabus, a universal template for engineering education, 32nd ASEE/IEEE Frontiers in Education Conference, Nov 6-9, 2002, Boston.

[6] Leong, H. (2007) Designing a CDIO programme: The CDIO syllabus and standards. Singapore Polytechnic. Available from http://www.kanazawa-it.ac.jp/cdio/english/file/slide10_leong.pdf. Accessed: 2017-10-01

[7] Podlesny, S. \& Kozlov, A. (2014) CDIO: objectives and means of achievement, Journal of the Association for Engineering Education of Russia. Vol 16, 2014 pp.7 - 11.

[8] Jiang Jin-gang, Zhang Yong-de, Shao Jun-peng, Sui Xiu-lin, Zhang Jian-yi (2014) Education and cultivation research of engineering undergraduate's innovative ability based on TRIZ-CDIO theory, The 9th International Conference on Computer Science \& Education (ICCSE 2014) August 22-24, 2014. Vancouver, Canada.

[9] Xun-tao Liu, Cun-you Zhao, Peng Xu (2011) TRTZ theory and students innovative ability cultivation, Higher Education Forum, No. 3, pp. 29-31, 2011.

[10] Jiang, F.; Sun, H. \& Wang, Y. (2010) Application of TRlZ theory in mechanical principle experiment teaching and management, Experiment Science \& Technology, No. 8, pp. 140-143, 2010.

[11] Chuchalin, A. (2014) Modernization of engineering education based on international CDIO standards, Engineering Education, Vol 16, 2014, pp 14 - 27. Available from http://aeer.ru/filesen/io/m16/IO-2014_16_eng.pdf. Accessed: 2017-10-01.

[12] Andreev, V., Pryanichnikov, V., Poduraev, Y., and Kuvshinov, S. (2014). Education on the basis of virtual learning robotics laboratory and group-controlled robots, in 24th DAAAM Int. Symp. on Intelligent Manufacturing and Automation, 2013, Procedia Engineering, 2014, vol. 69, pp. 35-40

[13] Malmqvist, J.; Edström, K. \& Hugo, R. (2017) A proposal for introducing optional cdio standards Proceedings of the 13th International CDIO Conference, University of Calgary, Calgary, Canada, June 18-22, 2017

[14] Taajamaa, V., Eskandari, M., Karanian, B., Airola, A., Pahikkala, T. \& Salakoski, T. (2016). O-CDIO: Emphasizing Design Thinking in the CDIO Engineering Cycle, International Journal of Engineering Education, 32(3B [14] Rowe, P. (1991). Design thinking. Cambridge, MA: MIT Press.

[15] Chong Siew Ping, Patrick Chow \& Christopher Teoh (2011) The use of design thinking in C-D-I-O projects, Proceedings of the 7th International CDIO Conference, Technical University of Denmark, Copenhagen, June 2011. Available from: http://www.wwwwww.cdio.org/files/document/file/70_paper.pdf. Accessed: 2017-10-01.

[16] Campbell, D. \& Beck, H. (2010). Toward internationalized engineering curriculum and student mobility. Proceedings of the 6th International CDIO Conference, Montréal, Canada.

[17] Enelund, M., Larsson, S., \& Malmqvist, J. (2011). Integration of computational mathematics in the mechanical engineering curriculum. Proceedings of the 7th International CDIO Conference, Lyngby, Denmark.

[18] Kontio, J. (2016) Enhancing quality together with CDIO community, Proceedings of the 12th International CDIO Conference, Turku University of Applied Sciences, Finland, June 12-16, 2016. Available from http://www.cdio.org/files/document/cdio2016/158/158_Paper_PDF.pdf. Accessed: 2017-10-01.

[19] Summary of proposals of the OSKA expert panel on the manufacturing of metal products, machinery and equipment (2016). Available from: http://oska.kutsekoda.ee/wp-content/uploads/2016/05/MMT_ENG.pdf. Accessed: 2017$10-01$

[20] Alan Crawford, A.; Mathews, S.; Makinster, J. \& Saul, W. (2005) Teaching and learning strategies for the thinking classroom. New York: The International Debate Education Association. Available from: https://pendidikanmatematikausn.files.wordpress.com/2015/11/teaching-and-learning-strategies.pdf. Accessed: 2017-10-01.

[21] Professional standards approved by the Cabinet of ministers of Republic of Latvia on May 18 th, 2010 by the rules Nr.461 